\title{
Recruitment of juvenile, captive-reared eastern loggerhead shrikes Lanius ludovicianus migrans into the wild population in Canada
}

\author{
E. L. Lagios, K. F. Robians, J. M. Lapierre, J. C. Steiner and T. L. Imlay
}

\begin{abstract}
High post-release survival, low dispersal and the recruitment of captive-reared individuals into the wild population are critical to the success of any reintroduction programme. Reintroducing a migratory species poses an additional challenge as success also depends on the return of captive-reared individuals to breeding grounds in subsequent years. We investigated the effects of seven husbandry and management factors on the return rate of captive-reared eastern loggerhead shrikes Lanius ludovicianus migrans and documented the recruitment of returning individuals. During 2004-2010, 564 juveniles were released in Ontario, Canada, as part of a field propagation and release programme and there were 27 confirmed sightings of returning birds during 2005-2011. Returning birds were significantly more likely to have been released in large groups of juveniles (9-10 birds) at 5.5 weeks post-fledging from the Carden field propagation site. Comparisons of the number of young fledged and survival to 2 weeks postfledging revealed similar results for pairs comprising one captive-reared and one wild-reared individual and pairs comprising two wild individuals. These results highlight the contribution of captive-reared shrikes to the recovery of the wild population and the importance of monitoring outcomes and evaluating techniques.
\end{abstract}

Keywords Breeding success, captive breeding, threatened species, Lanius ludovicianus migrans, loggerhead shrike, recruitment, reintroduction, return rate

\section{Introduction}

$\mathrm{R}$ eintroduction programmes are important conservation Rtools for re-establishing, augmenting or maintaining wild populations of threatened species by releasing captivereared individuals within their historical range (Cade \& Temple, 1995; Wolf et al., 1996; IUCN, 1998). Overall, the success of reintroductions has been variable (reviewed in Beck et al., 1994; Wolf et al., 1998; Fischer \& Lindenmayer, 2000) but there have been some notable successes, with the re-establishment of populations of peregrine falcon

E. L. Lagios, K. F. Robbins, J. M. Lapierre, J. C. Steiner and T. L. Imlay (Corresponding author) Wildlife Preservation Canada, 5420 Highway 6 North, Guelph, Ontario N1H 6J2, Canada. E-mail tara.imlay@gmail.com

Received 26 November 2012. Revision requested 11 January 2013.

Accepted 5 April 2013. First published online 1 May 2014.
Falco peregrinus (Tordoff \& Redig, 2001) and Mauritius kestrel Falco punctatus (Nicoll et al., 2004). Studies investigating the reasons for reintroduction success or failure have focused typically on post-release dispersal and survival (Tweed et al., 2003; Lockwood et al., 2005; Parish \& Sotherton, 2007; Bernardo et al., 2011; Mitchell et al., 2011), which are important factors for successful reintroduction. However, for migratory species success also depends on the return of captive-reared individuals to breeding grounds and subsequent recruitment into the wild breeding population (Maxwell \& Jamieson, 1997).

Although the loggerhead shrike is categorized as Least Concern on the IUCN Red List (BirdLife International, 2012), declines in shrike populations have been reported globally (Yosef, 1994). In Canada the migratory eastern subspecies of loggerhead shrike Lanius ludovicianus migrans is categorized as Endangered by the Committee on the Status of Endangered Wildlife in Canada (COSEWIC, 2000 ), with the current population estimated at $<30$ breeding pairs (Wildlife Preservation Canada, unpubl. data). A captive-breeding programme was initiated in 1997, with the recruitment of wild shrike nestlings to establish a safety-net population (Environment Canada, 2010). Since 2001, juvenile captive-reared shrikes have been released into the wild annually as part of an Ontario-based field propagation and release programme (Nichols et al., 2010). Field propagation and release involves the breeding of captive adults in field enclosures situated in historical breeding habitat, where young birds are parent-raised and subsequently released in situ (Nichols et al., 2010). Over 600 hatch-year birds have been released to date and the first captive-reared bird returned and bred successfully with a wild shrike in 2005 (Nichols et al., 2010). The mean annual return rate for captive-reared shrikes released during 2004-2007 was 4.6\% (range 2.0-6.6\%, Nichols et al., 2010), which is higher than the documented return rates of wild juvenile shrikes in other migratory North American populations (1.1\%, Kridelbaugh, 1983; 0\%, Brooks \& Temple, 1990; 1\%, Burton, 1990; 0.8\%, Haas, 1995; 0.85-1.2\%, Collister \& De Smet, 1997) but similar to the return rates reported for wild juveniles in Ontario during 2001-2003 (3-12\%, Okines \& McCracken, 2003). A study documenting the post-release survival and dispersal of captive-reared shrikes indicated that survival was higher (76\%, Imlay et al., 2010) than survival estimates for wild juvenile passerines (42\%, Anders et al., 1997; 60\%, Vega Rivera et al., 1998; 56-63\%, Wells et al., 2007). 


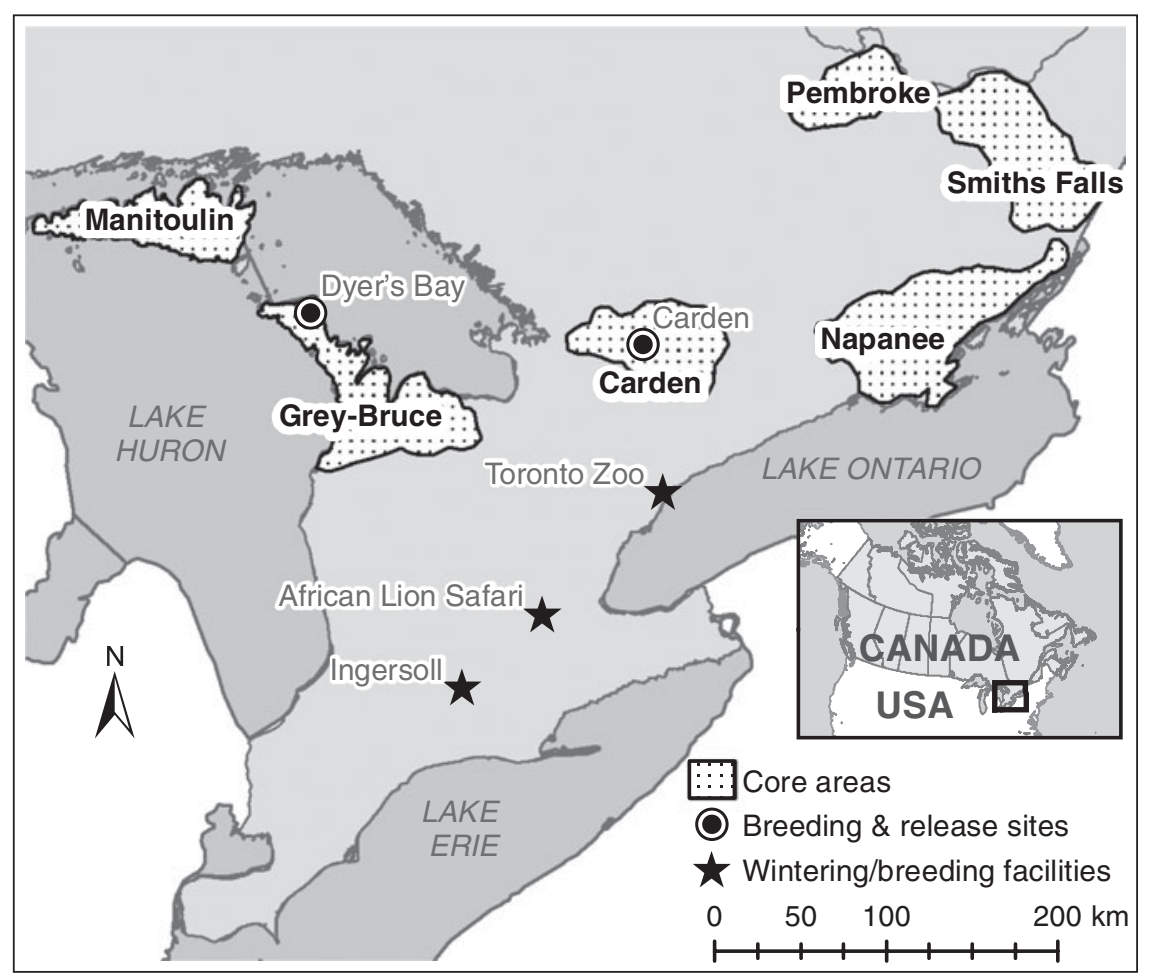

FIG. 1 Locations of historical core breeding areas for eastern loggerhead shrikes Lanius ludovicianus migrans in Ontario, Canada. The rectangle on the inset shows the location of the main map in Canada.
Reintroduction programmes can generate large quantities of field data, especially when animals are marked and monitored post-release (Sarrazin \& Barbault, 1996; Fischer \& Lindenmayer, 2000; Sutherland et al., 2010). For this programme, data were collected annually on a variety of management factors likely to affect the survival and recruitment of released individuals. Data on the techniques utilized may be relevant to analyses of the conditions experienced by prerelease juveniles (Armstrong \& Seddon, 2008; Ballou et al., 2010) and how this may affect their return rates. Several reintroduction studies have noted differences between the reproductive productivity of wild-reared and captive-reared individuals (Sarrazin et al., 1996; Brown et al., 2006; Roche et al., 2008), and therefore examining productivity following recruitment of captive-reared individuals will provide a better assessment of the capacity of the reintroduction programme to augment or re-establish an existing population.

We analysed the effect of seven variables (initial separation method, release site, release date, release age, release group size, sex and body condition) on return rates of captive-reared juvenile eastern loggerhead shrikes. We also compared the breeding success of captive-reared shrikes that have returned to breeding grounds and paired with wild shrikes with that of an extant population of wild shrikes in the Carden area (Fig. 1).

\section{Study area}

As part of the field propagation and release programme parent-reared juvenile shrikes were released simultaneously at two locations in southern Ontario, Canada: Dyer's Bay and Carden (Fig. 1). These locations occur within the historical breeding range of the species and consist of annually grazed pastures and short grassland habitat. One of the last two remaining breeding populations in the wild is found on the Carden Alvar (Fig. 1).

\section{Methods}

To investigate factors affecting the return rates of juvenile captive-reared eastern loggerhead shrikes we examined data compiled from the field propagation and release programme during 2004-2010 and from the wild population monitoring programme during 2005-2011. The Dyer's Bay and Carden field sites contained 12 and 14 outdoor breeding and release enclosures, respectively. Each year, from late April to early September, selected pairs of breeding adults were relocated from overwintering facilities at African Lion Safari, Ingersoll and the Toronto Zoo to the field enclosures. A detailed description of the field propagation and release programme, including management of breeding adults and juveniles, can be found in Nichols et al. (2010).

Fledged young were separated from their parents at a mean age of $44.5 \pm \mathrm{SD} 8.8$ days, or 3.5 weeks post-fledging, approximating when young become independent of adults in the wild (c. 4 weeks post-fledging; Pruitt, 2000; Chabot et al., 2001). At the field propagation sites separation occurred at 3-9 weeks post-fledging, when young were transferred to a predetermined release enclosure and grouped with other birds of approximately the same age. Young 
produced at the Ingersoll facility in $2004(n=6), 2005$ $(\mathrm{n}=5)$ and 2007-2009 ( $\mathrm{n}=3,14$ and 5, respectively) were transferred at 5-9 weeks post-fledging to one of the field sites for release. Young produced at the Toronto Zoo in 2010 $(n=3)$ were transferred at $4-5$ weeks post-fledging. Age at separation varied depending on the availability of release enclosures, the number of young at separation age among different broods, the breeding stage of adults (e.g. with second brood) and the capacity to transfer young from Ingersoll and the Toronto Zoo to the field propagation sites. All juveniles remained within release enclosures for 1-2 weeks and were monitored daily to ensure they had strong flight skills, were able to hunt and kill live vertebrate prey, and, if present, responded appropriately to predators flying overhead. Typically, juveniles were released when they reached 61.0 \pm SD 10.1 days old, or 4-11 weeks after fledging.

All juveniles were banded with a government-issue stainless steel identification band and up to three Darvic coloured bands 1-2 weeks prior to release. A subset of birds released from Carden in $2007(\mathrm{n}=18)$ and $2008(\mathrm{n}=20)$ were fitted with radio-transmitters as part of a study on post-release survival and dispersal (Imlay et al., 2010). A subset of birds released from both locations during 2009-2011 ( $\mathrm{n}=49,43$ and 16, respectively) were fitted with geolocators as part of a larger study to determine migration routes and wintering grounds (Wildlife Preservation Canada, unpubl. data).

In Ontario we collected data annually on the return rates and breeding success of captive-reared shrikes, following established protocols (WPC, 2011). We used annual reports (Wildlife Preservation Canada, unpubl. data) to compile data on 20 different husbandry and management factors for all captive-reared juveniles released during 2004-2010: breeding site (Dyer's Bay, Carden, Ingersoll or Toronto Zoo), parentage, breeding cage, clutch number (first, second, only), number of fledglings in clutch, hatch date, method of initial separation from parents (into an adjacent unit with access to parents through the mesh or into a completely separate release cage), initial separation date, age at separation, year released, release date, age at release, release group size, release site (Dyer's Bay or Carden), release cage, release technique (release cage, adjacent to parents or with parents), equipped with radio-tag or geolocator, body condition (ratio of mass to tarsus length) at banding, sex, and sibling mortality prior to release. Nichols et al. (2010) reported the number of young released during 2004-2007 and the number of returning individuals during 2005-2008; this information was included in the analyses.

We conducted an initial exploratory analysis to determine possible trends and identify key factors from the 20 variables to include in the final analysis. We used linear regression and analysis of variance (ANOVA) tests to identify correlated factors (e.g. hatch date and release date);
TABLE 1 The number of captive-reared eastern loggerhead shrikes Lanius ludovicianus migrans released during 2004-2010, the number of these that returned to the breeding site in Ontario, Canada (Fig. 1), and the year they returned.

\begin{tabular}{lccl}
\hline Cohort & $\begin{array}{l}\text { No. } \\
\text { released }\end{array}$ & $\begin{array}{l}\text { No. of returning } \\
\text { individuals }\end{array}$ & $\begin{array}{l}\text { Years returned } \\
\text { (no. of individuals) }\end{array}$ \\
\hline 2004 & 32 & 1 & $2005(1)$ \\
2005 & 54 & 1 & $2006(1)$ \\
2006 & 111 & 8 & $2007(4), 2008(2)$, \\
& & & $2009\left(1^{1}\right), 2010\left(2^{1}\right)$ \\
2007 & 94 & 8 & $2008(6), 2009(1)$, \\
& & & $2010\left(1^{2}\right), 2011\left(1^{2}\right)$ \\
2008 & 103 & 3 & $2009(3)$ \\
2009 & 94 & 4 & $2010(4)$ \\
2010 & 76 & 2 & \\
Total & 564 & 27 & \\
\hline
\end{tabular}

${ }^{1}$ One 2006-released bird returned in both 2009 and 2010.

${ }^{2}$ One 2007-released bird returned in both 2010 and 2011.

potentially confounding relationships were excluded. We excluded several variables from the analysis because of the small sample size of returning individuals or the small number of observations for some categories. This reduced the total number of husbandry and management factors to seven: (1) sex, (2) initial method used to separate birds from their parents, (3) release date, (4) age at release, (5) number of individuals in the release group, (6) release location and (7) body condition.

During 2004-2010 564 shrikes were released from the two field locations and we determined the full suite of seven variables for 487 individuals, including 15 of the 27 birds that returned to Ontario during 2005-2011 (Table 1). One shrike released from the discontinued Quebec captive-breeding and release programme was resighted in Ontario but was not included in the analysis. Only 16 returning birds were identified in the field by band combination and/or by confirmation of band number through live trapping (see Chabot, 2011 for methods). We could not confirm the body condition of one individual, and therefore only 15 were included in the analysis of factors affecting return rates. The remaining birds could not be identified individually and were not included as returning birds in the analysis because we could not ascertain their husbandry and management factors

We used a general linear model to examine the effects of the seven variables on return rates. We compared 21 iterations of the models with different combinations of variables, using Akaike's information criterion (AIC; Anderson et al., 2000).

We used Nichols et al. (2010) and annual reports from Wildlife Preservation Canada to compile data on resighted captive-reared birds, including their location, year resighted and breeding status (single or paired). We also used annual reports to compile data on the breeding success of all wild 
TABLE 2 Models for the rates of return of captive-reared eastern loggerhead shrikes to breeding grounds in Ontario, Canada (Fig. 1). The full model included seven parameters related to the husbandry and management of captive-reared juvenile shrikes (see Methods). Parameters are significant unless otherwise indicated. Only models with an AIC weight $>0.05$ are shown; 16 models are not shown.

\begin{tabular}{|c|c|c|c|c|c|}
\hline Model & AIC & $\Delta \mathrm{AIC}$ & AIC weight & $K^{1}$ & Deviance $^{2}$ \\
\hline Sex + release group size + release age + release site & 76.6 & 0.0 & 0.421 & 6 & 64.7 \\
\hline $\begin{array}{l}\text { Sex }+ \text { initial separation } \text { method }^{3}+\text { release date }^{4}+\text { release age }^{3} \\
+ \text { release group size }+ \text { release } \text { site }^{3}+\text { body condition }^{4}\end{array}$ & 78.0 & 1.4 & 0.214 & 9 & 60.0 \\
\hline Sex + release group size + release age + initial separation method $^{4}$ & 79.3 & 2.7 & 0.112 & 6 & 67.3 \\
\hline Sex + release group size + release age & 79.4 & 2.8 & 0.109 & 5 & 69.4 \\
\hline Sex + release group size + release age + release date ${ }^{4}$ & 79.9 & 3.3 & 0.082 & 6 & 67.9 \\
\hline
\end{tabular}

${ }^{1}$ No. of estimable parameters

${ }^{2}$ Residual deviance of model

${ }^{3}$ Parameter not significant $(0.05<\mathrm{P}<0.10)$

${ }^{4}$ Parameter not significant $(\mathrm{P}>0.10)$

pairs breeding in Carden during 2005-2011, including pairs comprising two wild-reared birds, one wild and one captivereared bird and two captive-reared birds. Indicators of breeding success included the number of young fledged from all nests, the number of young fledged from successful nests (i.e. nests that fledged at least one chick) and the number of young that survived to 2 weeks post-fledging. We used ANOVA tests to compare the indicators of breeding success between captive-wild and wild-wild pairings in Carden during 2005-2011. We only included Carden pairs in the analysis because the majority of captive-reared birds returned to this core area.

We performed all statistical analyses in $R v$. 2.14.1, with bbmle v. 1.o.4.1 (R Development Core Team, 2011).

\section{Results}

The best-fit model for the effect of husbandry and management factors on return rates for captive-reared shrikes included sex, size of release group $(\mathrm{P}<0.001)$, release age $(\mathrm{P}=0.013)$ and release site $(\mathrm{P}=0.042$; Table 2$)$. Unknown sex was significant $(\mathrm{P}<0.001)$, probably because of the variance attributable to the low proportion of birds of unknown sex that returned ( 1 of 398 ) compared to returned birds of known sex (female: 7 returned of 39 known; male: 7 returned of 50 known). There was no difference in the return rates of male and female birds $(P=0.377)$. The mean size of the release group was $9.0 \pm \mathrm{SD} 2.3$ for returning birds and $8.1 \pm \mathrm{SD} 2.3$ for non-returning birds. The mean release age was $57 \pm$ SD 8.1 days for returning birds and $59 \pm$ SD 8.6 days for non-returning birds. We noted a slight positive relationship between release group size and release age $\left(R^{2}=0.010\right.$, $\mathrm{df}=1,485, \mathrm{P}=0.015$ ). Juveniles released at the Carden site were more likely to return ( $4.2 \%$ returned; 11 of 263$)$ than those released in Dyer's Bay (1.8\% returned; 4 of 224).

The overall rate of return of known captive-reared juvenile shrikes released during 2004-2010 was 4.8\%
(Table 1). The majority of returning birds were first resighted in the year following their release $(78 \%, 21$ of 27$)$, however three, two and one birds were first resighted 2, 3 and 4 years after release, respectively. Two known birds returned in consecutive years, with both resighted 3 and 4 years after release.

Of the 27 captive-reared shrikes that returned to breeding grounds 18 paired with a wild bird (67\%) and 14 of these successfully fledged a total of 47 young $(78 \%$ breeding success between captive-wild pairings). There were no significant differences in breeding success between captive-wild and wild-wild pairings in Carden, comparing the number of young fledged $(\mathrm{F}=0.009, \mathrm{df}=1,98$, $\mathrm{P}=0.924)$, the number of young fledged from successful nests, i.e. nests that fledged at least one chick $(F=0.048$, $\mathrm{df}=1,76, \mathrm{P}=0.827$ ) and the number of young surviving to 2 weeks post-fledging $(\mathrm{F}=0.657, \mathrm{df}=1,75, \mathrm{P}=0.420$; Table 3). Two captive-reared birds paired together in 2010 and were not included in the above analysis; they produced a clutch of six eggs but no young fledged. The remaining seven captive-reared shrikes that returned to breeding grounds in Ontario did not pair and were considered single birds.

Captive-reared shrikes typically returned to the location from which they were released but we identified some connectivity between core areas. Of the eight returning captivereared shrikes known to be released from Dyer's Bay three returned to the Dyer's Bay field propagation site, one returned to the Grey-Bruce area and four were resighted c. $200 \mathrm{~km}$ east in the Carden area (Fig. 1). Of the 11 shrikes released from Carden 10 returned to Carden and one was resighted c. $250 \mathrm{~km}$ north-east near Quyon, Quebec, breeding with a wild shrike (Fig. 1). Quyon lies within the historical range of the species but breeding has not been recorded in this region since 1995 (Environment Canada, unpubl. data). One bird released from the discontinued Quebec captive-breeding and release programme was resighted in the Carden area. 
TABLE 3 Breeding success of captive-wild and wild-wild shrike pairs in Carden, Ontario, during 2005-2011, with mean no. of fledged young for all nests, mean no. of fledged young for successful nests and mean no. of fledged young surviving to 2 weeks post-fledging; probability values are provided from ANOVA tests. Nest checks were not conducted in the wild during 2006-2008, except for one captive-wild pair in 2007, and therefore the egg count for this period is unknown.

\begin{tabular}{|c|c|c|c|c|c|c|}
\hline \multirow[b]{2}{*}{ Pair composition } & \multicolumn{2}{|c|}{ Fledged young (all nests) } & \multicolumn{2}{|c|}{ Fledged young (successful nests ${ }^{1}$ ) } & \multicolumn{2}{|c|}{$\begin{array}{l}2 \text { weeks post-fledging } \\
\left(\text { successful nests }{ }^{2} \text { ) }\right.\end{array}$} \\
\hline & Mean \pm SD (n) & $\mathrm{P}$ & Mean \pm SD (n) & $\mathrm{P}$ & Mean \pm SD (n) & $\mathrm{P}$ \\
\hline Captive-wild & $2.7 \pm 2.0(16)$ & 0.924 & $3.6 \pm 1.3(12)$ & 0.827 & $2.7 \pm 1.7(12)$ & 0.420 \\
\hline Wild-wild & $2.7 \pm 1.9(85)$ & & $3.5 \pm 1.4(66)$ & & $3.1 \pm 1.5(64)$ & \\
\hline
\end{tabular}

${ }^{1} \mathrm{~A}$ successful nest was one that fledged at least one chick.

${ }^{2} \mathrm{~A}$ successful nest was one that had at least one fledgling surviving to 2 weeks post-fledging.

\section{Discussion}

The return of captive-reared and released individuals and their ultimate recruitment into the wild population are critical factors in the success of reintroduction programmes (Maxwell \& Jamieson, 1997). Juvenile eastern loggerhead shrikes that returned to breeding grounds came from larger release groups and were released at a younger age than their non-returning counterparts. Although these factors did not differ greatly between returning and nonreturning birds they represent aspects of the husbandry and management of avian captive-breeding programmes that are relatively easy to manipulate in an in situ propagation and release setting.

Young birds from the same clutch are typically grouped with similar-aged birds from other broods to form release groups. Larger groups of mixed broods may offer juveniles increased opportunity to engage in social learning with their peers prior to release. Socially acquired predator-detection and avoidance skills have been documented in corvids and ducks (see review in Griffin, 2004) and many experimental and observational studies of both wild and captive-reared passerines have shown that social learning is an important component in developing food choice and foraging habits (see review in Lefebvre \& Bouchard, 2003). Despite the prevalence of dispersing flocks of mixed-brood and mixedspecies juvenile passerines (Morton et al., 1991; Greenberg, 2000) Imlay et al. (2010) found that juvenile shrikes generally dispersed from the Carden release site independently. However, they also spent a mean of nearly 2 weeks at the release site prior to dispersing or migrating (Imlay et al., 2010). Larger release groups may result in more young birds utilizing the release site and present juvenile shrikes with another opportunity to learn from their peers prior to dispersal or migration.

Although larger release groups may offer significant benefits to young shrikes still developing survival skills, there may be a threshold beyond which the group is too large and young birds experience density-related stress within release enclosures. Crowding is a well-documented source of chronic stress in captivity (Teixeira et al., 2007), with adverse effects on both behaviour and health (Nephew et al., 2005; Parker et al., 2012). Birds experiencing crowded conditions in release enclosures may exhibit a reduced frequency of maintenance behaviours (e.g. feeding, drinking, preening; Nephew et al., 2005) and upon release may disperse quickly to alleviate their stress levels. This may leave them at a disadvantage with respect to their foraging and predator-avoidance skills and reduced access to supplemental food.

Both returning and non-returning birds were released at a minimum of 4 weeks post-fledging. Age was found to be the key predictor for post-fledging survival of red-bellied woodpeckers Melanerpes carolinus (Cox \& Kesler, 2012), with the highest mortality among passerines typically occurring within the first 2 weeks after fledging, as a result of predation (Anders et al., 1997; Naef-Daenzer et al., 2001; Kershner et al., 2004; Wells et al.; 2007). Releasing juvenile shrikes well after the vulnerable early post-fledging period and around the time they would become independent of parental care in the wild helps to maximize survival and ultimately recruitment (Nichols et al., 2010). However, older release birds have spent more time in captivity and may become increasingly dependent on supplied food if not given the opportunity to forage independently, despite the occasional presence of wild prey in the field enclosures. In a captive-breeding programme for pink pigeons Columba mayeri $83 \%$ of the birds were released at $<_{1}$ year old ( $n=42$, age range $72-3,850$ days; Jones et al., 1992). Ongoing supplemental feeding was considered essential for their management as it seemed likely that many of the birds would never be totally self-sufficient (Jones et al., 1992). Supplemental food is provided to juvenile shrikes for at least 1 week post-release and is gradually decreased as shrikes disperse from the release site (Nichols et al., 2010). Released captive-reared eastern loggerhead shrikes have low foraging success (16\%; Imlay \& Andrews, 2008) compared to that observed in wild and captive-reared San Clemente loggerhead shrikes Lanius ludovicianus mearnsi (Lynn et al., 2006). It is possible that older release birds are more dependent on 
supplemental food and that age affects foraging success post-release. Thus, although increased time in captivity may initially confer a survival benefit by reducing predation mortality there may be a threshold beyond which further time in captivity reduces overall survival of juveniles released into the wild (reviewed in Parker et al., 2012).

We found that birds released in Carden were more likely to return than those released in Dyer's Bay and many of the birds released in Dyer's Bay were resighted in Carden. The Carden area provides habitat for the largest remaining wild population in Ontario (c. 15 pairs annually), whereas fewer than two wild pairs have been documented annually in Grey-Bruce over the last decade (Wildlife Preservation Canada, unpubl. data). Conspecific attraction has been hypothesized as being an important factor in the selection of breeding territory by loggerhead shrikes (Etterson, 2003; Glynn-Morris, 2010) and may also be important for increasing the rate of return to an area with a pre-existing wild population (Ward \& Schlossberg, 2004). Alternatively, Carden may contain more suitable habitat for shrikes, as indicated by the larger, more concentrated wild population there. A population viability analysis indicated that the recruitment of captive-released birds in Carden had reversed the declining population trend in this area but that the growth rate was not as strong as initially predicted (Tischendorf, 2009). It has been suggested that conditions on the wintering grounds that affect the survival and recruitment of juvenile shrikes (both wild and captivereared) are hindering the recovery of the wild population (Tischendorf, 2009).

There are many factors that influence the success of reintroduction projects (reviewed in Parker et al., 2012) and reintroducing a migratory passerine poses additional challenges because released individuals must migrate and return to their breeding grounds before being recruited into the breeding population. Specific challenges unique to reintroducing migratory species relate to migration routes (Bowden et al., 2011), survival during migration (Mari et al., 2010), overwintering survival (Tischendorf, 2009), establishment on wintering ground (Mari et al., 2010), return rates (Newbery, 2010) and understanding the factors that influence these important population dynamics. Captivereared shrikes have returned at a higher rate than their wild counterparts (Nichols et al., 2010) but our evaluation and analysis of the outcomes of captive management and release techniques suggest that return rates of juvenile shrikes can be improved further. Ultimately the goal of any captivebreeding and release programme is the recruitment of captive-reared individuals into the breeding population. The majority of returning captive-reared shrikes in our study paired with wild shrikes and the proportion of captive-wild pairs that successfully produced young (75\%) was similar to that for wild-wild pairs $(78 \%)$. This is higher than the productivity recorded in other avian captive-breeding and release programmes (e.g. $60 \%$ in captive-wild takahe Porphyrio mantelli pairings, Maxwell \& Jamieson, 1997; 16\% in captive-wild aplomado falcon Falco femoralis septentrionalis pairings, Brown et al., 2006). Roche et al. (2008) found that captive-reared pairs of piping plovers Charadrius melodus had lower breeding success than wild pairs and suggested that captive-reared birds were less able to identify suitable habitat or recognize threats. Given that breeding success did not differ for captive-wild and wild-wild shrike pairs it seems likely that the field propagation programme provides a suitable environment for young shrikes to learn the necessary skills for surviving in the wild and that by pairing with a wild shrike captivereared individuals learn additional behaviours necessary for successfully producing young in the wild.

Our findings indicate that the conditions experienced by captive-reared juvenile shrikes prior to release can affect the rates at which they return to breeding grounds. Of the factors involved in the husbandry and management of juvenile shrikes in captivity, release group size and age at release are significant factors that can be manipulated to improve return rates. When possible, shrikes should be released at 5.5 weeks post-fledging in groups of 9-10 juveniles. The high pre-migration survival (Imlay et al., 2010) and return rates of captive-reared juveniles (Nichols et al., 2010) and their successful integration into the wild population suggest that the field propagation and release programme is producing and releasing young capable of adapting to the wild. By evaluating the techniques used in this programme husbandry practices can be modified to increase the likelihood that released birds will return to breeding grounds, thus improving the effectiveness of the reintroduction programme. Similar approaches are recommended for other captive-breeding and release programmes, particularly for migratory species.

\section{Acknowledgements}

Funding for the field propagation and release programme was largely provided by Environment Canada-Canadian Wildlife Service through an agreement with Wildlife Preservation Canada. Additional funding was provided by Boisset Family Estates, the Ontario Ministry of Natural Resources Species at Risk Research Fund and Species at Risk Stewardship Fund, the Ontario Trillium Foundation and Wildlife Preservation Canada. We thank all the individuals and partner organizations involved in the field propagation and release effort, including African Lion Safari, the Avian Science and Conservation Centre at McGill University, Bird Studies Canada, Canadian Association of Zoos and Aquariums, A. Chabot, the Couchiching Conservancy, Environment Canada-Canadian Wildlife Service, B. and B. McNair, R. Snider, K. Tuininga, Toronto Zoo, and N. and 
C. Turnbull. A. Chabot undertook the trapping and banding of returning captive-reared shrikes and developed the banding scheme. G. Robertson kindly provided assistance with data analysis and modelling. Comments from A. Chabot, B. Stutchbury, E. Williams, F. Shaffer, J.P. Savard, M. Smith and two anonymous reviewers greatly improved this article. Finally, this programme would not be possible without the invaluable assistance of field staff and volunteers and the support of local landowners.

\section{References}

Anders, A.D., Dearborn, D.C., Faaborg, J. \& Thompson, F.R. (1997) Juvenile survival in a population of neotropical migrant birds. Conservation Biology, 11, 698-707.

Anderson, D.R., Burnham, K.P. \& Thompson, W.L. (200o) Null hypothesis testing: problems, prevalence, and an alternative. The Journal of Wildlife Management, 64, 912-923.

Armstrong, D.P. \& Seddon, P.J. (2008) Directions in reintroduction biology. Trends in Ecology and Evolution, 23, 20-25.

Ballou, J.D., Lees, C., Faust, L.J., Long, S., Lynch, C., Bingaman Lackey, L. \& Foose, T.J. (2010) Demographic and genetic management of captive populations. In Wild Mammals in Captivity: Principles and Techniques for Zoo Management (eds D.G. Kleiman, K.V. Thompson \& C.K. Baer), pp. 219-252. University of Chicago Press, Chicago, USA.

Beck, B.B., Rapaport, L.G., Stanley Price, M.R. \& Wilson, A.C. (1994) Reintroduction of captive-born animals. In Creative Conservation: Interactive Management of Wild and Captive Animals (eds P.J.S. Olney, G.M. Mace \& A.T.C. Feistner), pp. 265-286. Chapman \& Hall, London, UK.

Bernardo, C.S.S., Lloyd, H., Olmos, F., Cancian, L.F. \& Galetti, M. (2011) Using post-release monitoring data to optimize avian reintroduction programs: a 2-year case study from the Brazilian Atlantic Rainforest. Animal Conservation, 14, 676-686.

BirdLife International (2012) Lanius ludovicianus. In IUCN Red List of Threatened Species v. 2013.2. Http://www.iucnredlist.org [accessed 23 February 2014].

Bowden, C.G.R., Hamoud, A., Jbour, S., Fritz, J., Peske, L., Riedler, B. et al. (2011) Attempted supplementation of the relict wild eastern population of northern bald ibis in Syria with Turkish semi-wild juveniles. In Global Re-introduction Perspectives: Re-introduction Case-Studies from Around the Globe (ed. P.S. Soorae), pp. 130-134. IUCN/SSC Re-introduction Specialist Group, Abu Dhabi, UAE.

Brooks, B.L. \& Temple, S.A. (1990) Dynamics of a loggerhead shrike population in Minnesota. Wilson Bulletin, 102, 441-450.

Brown, J.L., Collopy, M.W., Gott, E.J., Juergens, P.W., Monotoya, A.B. \& Hunt, W.G. (2006) Wild-reared aplomado falcons survive and recruit at higher rates than hacked falcons in a common environment. Biological Conservation, 131, 453-458.

Burton, K.M. (1990) Loggerhead shrike update. Indiana Audubon Quarterly, 68, 57-58.

Cade, T.J. \& Temple, S.A. (1995) Management of threatened bird species: evaluation of the hands-on approach. Ibis, 137, 161-172.

Снавот, A.A. (2011) 2011 Ontario Loggerhead Shrike Banding Summary. Unpublished report. Environment Canada, Ontario, Canada.

Снавот, A.A., Bird, D.M. \& Titman, R.D. (2001) Breeding biology and nest success of loggerhead shrikes in Ontario. Wilson Bulletin, $113,285-289$.
Collister, D.M. \& De Smet, K. (1997) Breeding and natal dispersal in the loggerhead shrike. Journal of Field Ornithology, $68,273-282$.

COSEWIC (Committee On The Status Of Endangered Wildifife In CANada) (2000) COSEWIC Assessment and Update Status Report on the Loggerhead Shrike migrans Subspecies, Lanius ludovicianus migrans in Canada. Committee on the Status of Endangered Wildlife in Canada, Ottawa, Canada.

Cox, A.S. \& Kesler, D.C. (2012) Reevaluating the cost of natal dispersal: post-fledging survival of red-bellied woodpeckers. Condor, 114, 341-347.

Environment Canada (2010) Recovery Strategy for the Loggerhead Shrike, migrans Subspecies (Lanius ludovicianus migrans), in Canada [Proposed]. Species at Risk Act Recovery Strategy Series. Environment Canada, Ottawa, Canada.

Etterson, M.A. (2003) Conspecific attraction in loggerhead shrikes: implications for habitat conservation and reintroduction. Biological Conservation, 114, 199-205.

Fischer, J. \& Lindenmayer, D.B. (2000) An assessment of the published results of animal relocations. Biological Conservation, 96, 1-11.

Glynn-Morris, M. (2010) Breeding habitat selection by the loggerhead shrike in Ontario: a hierarchical analysis. BSc thesis. Queens University, Kingston, Canada.

Greenberg, R. (2000) Birds of many feathers: the formation and structure of mixed-species flocks of forest birds. In On the Move: How and Why Animals Travel in Groups (eds S. Boinski \& P.A. Garber), pp. 521-558. University of Chicago Press, Chicago, USA.

Griffin, A.S. (2004) Social learning about predators: a review and prospectus. Learning and Behavior, 32, 131-140.

HAAs, C.A. (1995) Dispersal and use of corridors by birds in wooded patches on an agricultural landscape. Conservation Biology, 9, 845-854.

Imlay, T. \& Andrews, D. (2008) Post-release Movement, Habitat Use and Survival of Juvenile Captive-bred Eastern Loggerhead Shrikes (Lanius ludovicianus migrans) in Carden Plain, Ontario. Unpublished report. Wildlife Preservation Canada, Guelph, Canada.

Imlay, T.L., Crowley, J.F., Argue, A.M., Steiner, J.C., Norris, D. R. \& Stutchiury, B.J.M. (2010) Survival, dispersal and early migration movements of captive-bred juvenile eastern loggerhead shrikes (Lanius ludovicianus migrans). Biological Conservation, 143, 2578-2582.

IUCN (1998) Guidelines for Re-introductions. Prepared by the IUCN/ SSC Re-introduction Specialist Group. Gland, Switzerland \& Cambridge, UK.

Jones, C.G., Swinnerton, K.J., Taylor, C.J. \& Mungroo, Y. (1992) The release of captive-bred pink pigeons Columba mayeri in native forest on Mauritius. A progress report July 1987-June 1992. Dodo, 28, $92-125$.

Kershner, E.L., Walk, J.W. \& Warner, R.E. (2004) Postfledging movements and survival of juvenile eastern meadowlarks (Sturnella magna) in Illinois. The Auk, 121, 1146-1154.

Kridelbaugh, L. (1983) Nesting ecology of the loggerhead shrikes in central Missouri. Wilson Bulletin, 95, 303-308.

Lefebvre, L. \& Bouchard, J. (2003) Social learning about food in birds. In The Biology of Traditions: Models and Evidence (eds D.M. Fragaszy \& S. Perry), pp. 94-126. Cambridge University Press, Cambridge, UK.

Lockwood, M.A., Griffin, C.P., Morrow, M.E., Randel, C.J. \& SiLvy, N.J. (2005) Survival, movements, and reproduction of released captive-reared Attwater's prairie-chicken. The Journal of Wildlife Management, 69, 1251-1258. 
Lynn, S., Martin, J.A. \& Garcelon, D.K. (2006) Can supplemental foraging perches enhance habitat for endangered San Clemente loggerhead shrikes? Wilson Journal of Ornithology, 118, 333-340.

Mari, F., Aebischer, A., Albertini, E., Wehrle, M. \& Bellani, A. (2010) Experimental release of young captive-bred black storks in Ticino Region Park-Lombardy, Italy: as potential support to the wild population. In Global Re-introduction Perspectives: Re-introduction Case-Studies from Around the Globe (ed. P.S. Soorae), pp. 139-142. IUCN/SSC Re-introduction Specialist Group, Abu Dhabi, UAE.

MAXWELL, J.M. \& JAMieson, I.G. (1997) Survival and recruitment of captive-reared and wild-reared takahe in Fiordland, New Zealand. Conservation Biology, 11, 683-691.

Mitchell, A.M., Wellicome, T.I., Brodie, D. \& Cheng, K.M. (2011) Captive-reared burrowing owls show higher site-affinity, survival, and reproductive performance when reintroduced using a soft-release. Biological Conservation, 144, 1382-1391.

Morton, M.L., Wakamatsu, M.W., Pereyra, M.E. \& Morton, G.A. (1991) Postfledging dispersal, habitat imprinting, and philopatry in a montane, migratory sparrow. Ornis Scandinavica, 22, 98-106.

Naef-Daenzer, B., Widmer, F. \& Nuber, M. (2001) Differential post-fledgling survival of great and coal tits in relation to their condition and fledging date. Journal of Animal Ecology, 70, $730-738$.

Nephew, B.C., Aaron, R.S. \& Romero, L.M. (2005) Effects of arginine vasotocin (AVT) on the behavioral, cardiovascular, and corticosterone responses of starlings (Sturnus vulgaris) to crowding. Hormones and Behavior, 47, 280-289.

Newbery, P. (2010) Re-introduction of corncrakes in the UK. In Global Re-introduction Perspectives: Re-introduction Case-Studies from Around the Globe (ed. P.S. Soorae), pp. 124-127. IUCN/SSC Re-introduction Specialist Group, Abu Dhabi, UAE.

Nichols, R.K., Steiner, J., Woolaver, L.G., Williams, E., Cнавот, A.A. \& Tuininga, K. (2010) Conservation initiatives for an endangered migratory passerine: field propagation and release. Oryx, 44, 171-177.

Nicoll, M.A.C., Jones, C.G. \& Norris, K. (2004) Comparison of survival rate of captive-reared and wild-bred Mauritius kestrels (Falco punctatus) in a re-introduced population. Biological Conservation, 118, 539-548.

Okines, D. \& McCracken, J. (2003) Loggerhead Shrike Banding in Ontario: Report on the 2003 Field Season. Unpublished report. Bird Studies Canada, Port Rowan, Canada.

Parish, D.M.B. \& Sotherton, N.W. (2007) The fate of released captive-reared grey partridges Perdix perdix: implications for reintroduction programmes. Wildlife Biology, 13, 140-149.

Parker, K.A., Dickens, M.J., Clarke, R.H. \& Lovegrove, T.G. (2012) The theory and practice of catching, holding, moving and releasing animals. In Reintroduction Biology: Integrating Science and Management (eds J.G. Ewen, D.P. Armstrong, K.A. Parker \& P.J. Seddon), pp. 105-137. Wiley-Blackwell, Oxford, UK.

PruitT, L. (2000) Loggerhead Shrike Status Assessment. Unpublished report. U.S. Fish and Wildlife Service, Bloomington, USA.

R Development Core Team (2011) R: A Language and Environment for Statistical Computing. R Foundation for Statistical Computing, Vienna, Austria.

Roche, E.A., Cuthbert, F.J. \& Arnold, T.W. (2008) Relative fitness of wild and captive-reared piping plovers: does egg salvage contribute to recovery of the endangered Great Lakes population? Biological Conservation, 141, 3079-3088.
Sarrazin, F., Bagnolini, C., Pinna, J.L. \& Danchin, E. (1996) Breeding biology during establishment of reintroduced griffon vulture Gyps fulvus population. Ibis, 138, 315-325.

Sarrazin, F. \& Barbault, R. (1996) Reintroduction: challenges and lessons for basic ecology. Trends in Ecology and Evolution, 11, $474-478$.

Sutherland, W.J., Armstrong, D., Butchart, S.H.M., Earnhardt, J.M., Ewen, J., Jamieson, I. et al. (2010) Standards for documenting and monitoring bird reintroduction projects. Conservation Letters, 3, 229-235.

Teixeira, C.P., De Azevedo, C.S., Mendl, M., Cipreste, C.F. \& YounG, R.J. (2007) Revisiting translocation and reintroduction programmes: the importance of considering stress. Animal Behavior, 73, 1-13.

Tischendorf, L. (2009) Population Viability Analysis of the Eastern Loggerhead Shrike (Lanius ludovicianus migrans), Version 2. Environment Canada-Canadian Wildlife Service, Ontario, Canada.

Tordoff, H.B. \& Redig, P.T. (2001) Role of genetic background in the success of reintroduced peregrine falcons. Conservation Biology, $15,528-532$.

Tweed, E.J., Foster, J.T., Woodworth, B.L., Oesterle, P., Kuehler, C., Lieberman, A.A. et al. (2003) Survival, dispersal, and home-range establishment of reintroduced captive-bred puaiohi, Myadestes palmeri. Biological Conservation, 111, 1-9.

Vega Rivera, J.H., Rappole, J.H., McShea, W.J. \& HaAs, C.A. (1998) Wood thrush postfledging movements and habitat use in northern Virginia. Condor, 100, 69-78.

WARD, M.P. \& S Chlossberg, S. (2004) Conspecific attraction and the conservation of territorial songbirds. Conservation Biology, 18, 519-525.

Wells, K.M.S., Ryan, M.R., Millspaugh, J.J., Thompson, F.R. \& HubBard, M.W. (2007) Survival of post-fledging grassland birds in Missouri. Condor, 109, 781-794.

Wolf, C.M., Garland, T. Jr \& Griffith, B. (1998) Predictors of avian and mammalian translocation success: reanalysis with phylogenetically independent contrasts. Biological Conservation, 86, 243-255.

Wolf, C.M., Griffith, B., Reed, C. \& Temple, S.A. (1996) Avian and mammalian translocations: update and reanalysis of 1987 survey data. Conservation Biology, 10, 1142-1154.

WPC (Wildlife Preservation Canada) (2011) Loggerhead Shrike, migrans Subspecies Recovery in Ontario: Habitat Surveying and Population Monitoring Field Protocols. Unpublished report. Wildlife Preservation Canada, Guelph, Canada.

Yosef, R. (1994) Evaluation of the global decline in the true shrikes (Family Laniidae). Auk, 111, 228-233.

\section{Biographical sketches}

ERICA L. LA GIO S has worked on conservation programmes in Canada and the United States, focusing on avian population monitoring and species recovery. KATHERINE F. RoBbins has worked on avian population monitoring programmes and species recovery efforts in Canada. JANET M. LAPIERRE has participated in avian conservation programmes in Canada and the United States and her research interests include sexual selection within avian populations and recovery efforts for threatened species. JESSICA C. STEINER has worked on captive-breeding and threatened species programmes in Mauritius, Australia and Canada. TARA L. IMLAy has worked on conservation programmes in Canada, Mauritius and the United States. Her research interests focus on the ecology of threatened species and the application of research to recovery programmes. 